Journal of European Public Policy

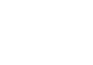

ISSN: 1350-1763 (Print) 1466-4429 (Online) Journal homepage: https://www.tandfonline.com/loi/rjpp20

\title{
Rising despite the polycrisis? The European Parliament's strategies of self-empowerment after Lisbon
}

\section{Katharina L. Meissner \& Magnus G. Schoeller}

To cite this article: Katharina L. Meissner \& Magnus G. Schoeller (2019) Rising despite the polycrisis? The European Parliament's strategies of self-empowerment after Lisbon, Journal of European Public Policy, 26:7, 1075-1093, DOI: 10.1080/13501763.2019.1619187

To link to this article: https://doi.org/10.1080/13501763.2019.1619187
(2) 2019 The Author(s). Published by Informa UK Limited, trading as Taylor \& Francis Group
曲 Published online: 30 May 2019.

Џلll Article views: 873

View Crossmark data $₫$
+ View supplementary material

Submit your article to this journal

Q View related articles $\asymp$

4 Citing articles: 1 View citing articles $\pi$ 


\title{
Rising despite the polycrisis? The European Parliament's strategies of self-empowerment after Lisbon
}

\author{
Katharina L. Meissner and Magnus G. Schoeller \\ Centre for European Integration Research (EIF), Department for Political Science, University of \\ Vienna, Vienna, Austria
}

\begin{abstract}
The European Union (EU) is currently enmeshed in a polycrisis. Yet, a treaty change to ease these crises is out of reach. We ask how a supranational actor, the European Parliament (EP), strives for more de facto powers amidst this situation. Relying on refined propositions of inter-institutional bargaining theory, we argue that the EP skilfully deploys strategies in order to extend its powers beyond the provisions of the Lisbon Treaty. Based on original interview material, we assess these propositions in two crisis-ridden areas of EU decisionmaking: economic governance and the negotiation of trade agreements. We find that the EP extended its powers in both policies by applying a set of particular strategies, which include obstructing the decision-making process, acting as a first-mover and mobilizing the public. Finally, we reflect on the possible consequences of this self-empowerment for the EP's legitimacy.
\end{abstract}

KEYWORDS Economic governance; European Integration; European Parliament; informal politics; trade

\section{Introduction}

The European Union (EU) is currently enmeshed in a polycrisis (Zeitlin et al. 2019). Yet, a treaty change to ease these crises is out of reach. Against this background, we ask how a supranational actor, the European Parliament $(E P)$, increased its powers in two crisis-ridden policies: economic governance and the shaping of trade agreements. Both policies produced major, yet contested decision-making outputs. In economic governance, the distributional effects of eurozone crisis management affect large parts of the European public in a drastic manner. As regards trade policy, the public is concerned about free trade agreements because of their impact on European regulatory standards. 
Drawing on a refinement of interstitial institutional change (Héritier 2007) and the EP's informal involvement in EU decision-making (Reh et al. 2013), we argue that the EP managed to incrementally extend its de facto powers in economic governance and the shaping of trade agreements. This was a result of skilfully deploying bargaining strategies.

The contribution of our paper is twofold. First, on a theoretical level, we add to the debate about the EP's (self-)empowerment (Farrell and Héritier 2003; Hix and Høyland 2013) by providing an encompassing list of refined bargaining strategies, and by inductively investigating conditions of success or failure. Second, whereas existing analyses have usually focused on only one EU policy (e.g., Bressanelli and Chelotti [2018]), we adopt a wider perspective on the EP's post-Lisbon empowerment by assessing our propositions in a cross-policy comparison.

In the next section, we argue that actors renegotiate formal rules in order to enhance their formal or informal institutional rights. Specifying further, we theorize the bargaining strategies with which the EP may seek to expand its rights. In a second step, we rely on semi-structured interviews with EU officials to analyze how the EP obtained further rights in economic governance and the shaping of trade agreements, and we assess where it failed with its demands.

\section{Theory: bargaining-based rational institutionalism}

Whereas the extent of the EP's influence on policy outcomes, particularly in the area of economic governance, is contested (Bressanelli and Chelotti 2018; Fromage 2018), scholars acknowledge that the EP's institutional powers have increased since the Lisbon Treaty (Fasone 2014). In line with recent research, we contend that the EP itself plays a crucial role in widening its powers. Yet, we know little about the conditions of how the EP reaches an empowerment through bargaining strategies.

A promising lens towards this end is a bargaining-based theory of institutional change (Héritier 2007: 40-66). According to this approach, actors seek to maximize their institutional power. In doing so, they may take advantage of ambiguities in incomplete contracts (Majone 2010: 154) and re-negotiate formal rules in the course of their application in order to obtain formal or informal institutional change to their benefit (Farrell and Héritier 2003, 2007). This takes the form of a bargaining process where actors with limited formal institutional rights, such as the EP, rely on a set of strategies to obtain further powers.

\section{The EP's bargaining strategies}

The EP's bargaining power relies on its (limited) formal rights granted by the Lisbon Treaty, its relative insensitivity to failure, and its longer time horizon in decision-making (Farrell and Héritier 2003). Based on these advantages, the EP 
can use pre-existing formal rights to obstruct the decision-making process and thereby gain further institutional powers. First, where the EP's opinion or consent is needed, it can delay decision-making until it obtains further institutional rights (see Gino and Moore 2008: 374). Second, the EP can sanction other actors by blocking a decision entirely if it has not been conceded additional rights. The aim of this strategy is to reach an empowerment at $t_{2}$ based on an earlier sanctioning at $t_{1}$.

Moreover, the EP can pursue a strategy of issue linking either within an arena of decision-making or across arenas. An arena is an institutional setting that determines the participants and the rules of decision-making. Within one arena, the EP can link its institutional demands with the support for a policy issue. Only if it obtains an institutional empowerment, will it support the contested issue. If the EP's support is not needed (because it lacks the power to block the outcome in one arena), it may link its request to the outcome of another arena, where it has a veto right (arena linking, Farrell and Héritier 2007: 292).

Given that the EP's formal decision-making rights are limited, it also has to use more indirect strategies. One such strategy is building alliances with actors that have formal rights in decision-making (see Liefferink and Andersen 1998: 256). Through lobbying formal decision-makers, the EP can add its requests for more institutional rights to the decision-making process.

In the absence of opportunities to build alliances, the EP can strive to increase costs for other actors in case it is not empowered. One way of doing so is moving first and 'inventing' a new institutional rule (see Héritier 1996; Liefferink and Andersen 1998: 256). In this case, other actors may either try to prevent the EP from moving first or return to the status quo ante. However, both options are often costly. Next to time and staff, member state governments may suffer electoral costs if the public perceives the EP's self-empowerment as legitimate.

A second strategy that increases the costs for other actors is mobilizing public opinion. By cooperating with media or non-governmental organizations (NGOs), the EP can mobilize public opinion on the grounds of democratic norms. This strategy comes close to 'shaming' (Rittberger and Schimmelfennig 2006). However, we do not assume that legitimacy norms are a constraint for actors in the bargaining process (Schimmelfennig 2001: 63). Rather, we assume that mobilizing public opinion can cause electoral costs for those governments that do not support the EP's empowerment.

In summary, we argue that change of formal institutional rules into redesigned formal or informal ones takes the form of a bargaining process in which the EP employs the following strategies to obtain an institutional empowerment: 
(1) Obstructing

(a) Delaying

(b) Sanctioning

(2) Issue-linking

(a) within an arena

(b) across arenas (arena linking)

(3) Allying with member states

(4) Moving first

(5) Mobilizing public opinion.

\section{Types of EP empowerment}

As we are interested in the current role of the EP, the starting point of our analysis will be the EP's formal rights when the Lisbon Treaty entered into force. Based on these rules, we assess the extent to which the EP obtained any formal or informal rights that go beyond the Lisbon provisions. Categorizing these rights, we distinguish two areas in which the EP strives for empowerment: (1) accountability and (2) decision-making. These are two crucial features of parliaments (Müller et al. 2003).

Measures of accountability in economic governance and trade policy according to the Lisbon Treaty are primarily based on articles 121 and 218 TFEU (Treaty on the Functioning of the EU), respectively. In economic governance, the EP needs to be informed by the Council about its policy guidelines and the results of the so-called 'multilateral surveillance' of member states' compliance with those guidelines. In trade policy, the EP has the right to be informed by the Commission about negotiations of international agreements. However, the degree to which other actors are obliged to inform the EP is not specified. We therefore understand accountability rights that go beyond the Lisbon Treaty as: (1a) any additional scrutiny tools or reporting activities from other actors to the $E P$, and (1b) any measures that cover further access to documents or data. These formal or informal rights can be observed through inter-institutional agreements or practices of coordination and sharing information between the EP and other actors.

Regarding decision-making, article 121.6 TFEU grants the EP co-decision rights for multilateral surveillance. This is, however, only one part of economic governance. Article 218.6 TFEU codifies the EP's right to consent to international (trade) agreements. We distinguish two ways the EP can go beyond these rights: it can gain the formal or informal right to (2a) directly participate in decision-making fora for which the Lisbon Treaty did not grant it a role, or (2b) get involved in venues or procedures through which it can exert indirect influence, such as appointment procedures for executive staff or meetings with decision-makers outside the official procedure. In such 
meetings, not foreseen by the Lisbon Treaty, the EP can feed demands into decision-making by lobbying relevant actors. The trade negotiations between the EU and Colombia and Peru are an example. Here, the EP addressed the countries directly and successfully asked for improvements of the labour rights situation (Héritier et al. 2015).

In brief, we understand the EP's empowerment as any formal or informal right of accountability or decision-making that goes beyond the provisions of the Lisbon Treaty:

(1) Accountability

(a) Enhancement of reporting and scrutiny tools

(b) Access to documents and data

(2) Decision-making

(a) Participation in decision-making fora

(b) Involvement in venues outside the official fora

\section{Methods and case selection}

In this paper, we seek to understand how the increase of the EP's formal or informal rights after Lisbon came about. We proceed in three steps. First, we assess the extent to which the EP received further formal or informal rights on the dimensions of accountability and decision-making. As we are interested in how the EP extended its powers, we report 'successful' cases of institutional empowerment in economic governance and the negotiation of trade agreements. Second, we examine how the EP was empowered in these cases by relying on a qualitative comparison in combination with 'explaining-outcome process-tracing'. We thus seek to account for the causal path that led to the outcome of interest. Applying a deductive approach, we examine whether the bargaining strategies identified in the previous theory section can account for the outcomes of EP empowerment (Beach and Pedersen 2013: 18-21). Third, we explore negative cases where the EP failed with its demands, and inductively assess the conditions for why the respective strategies failed.

Our case selection therefore covers positive and negative cases from the areas of economic governance and the shaping of trade agreements. Negative cases help us refine the conditions under which the identified bargaining strategies lead to institutional change to the benefit of the EP. In other words, 'negative cases can ensure that the mechanism proposed to produce the outcome in positive cases is not at work in the negative cases as well' (Mikkelsen 2017: 742) and can thus lend supporting evidence to how a bargaining strategy produces a certain outcome in positive cases. In choosing our negative cases, we rely on the rule of inclusion proposed by Mahoney and Goertz 
(2004: 657). According to this rule, we perceive a negative case as relevant for our study if the EP (could have) used a bargaining strategy but nonetheless failed with its demand in one of the areas under investigation.

While we relied on legislative texts in order to identify new formal rights that deviate from the Lisbon Treaty, we drew primarily on interview material to obtain information on de facto informal rights and strategies used by the EP. More precisely, we relied on 14 semi-structured interviews with EU officials who were directly involved in the issues under investigation. These were officials working in the Commission's Directorates General (DG) ECFIN and Trade, the General Secretariat of the Council, as well as the secretariats of EP Committees ECON, LIBE and INTA, next to a Member of the EP (MEP) as well as staff of MEPs and the EP Research Service. We interviewed officials with varying institutional affiliations, including (but not restricted to) the EP, as well as from different positions in order to filter out biases resulting from affiliation or rank of respondents and to verify correctness of information. In order to obtain relevant information, we guaranteed confidentiality to the interviewees.

\section{EP empowerment in economic governance and trade agreements}

By the end of 2009, the outbreak of the eurozone crisis coincided with the entry into force of the Lisbon Treaty, which for the first time granted the EP co-decision rights in economic governance. Instances of institutional change, in which the EP was successful in obtaining further powers, are the Six-pack and Two-pack legislation, but also the intergovernmental Fiscal Compact (Fasone 2014; O'Keeffe et al. 2016; Rittberger 2014). The EP's role in the negotiation of trade agreements also became a focus of research after the Lisbon Treaty had granted the EP the right to consent to such agreements (Jančić 2016). Two cases in which the EP was successful in expanding its informal rights are the negotiations on the SWIFT agreement and TTIP (on hold since 2016). Table 1 (online appendix) summarizes the EP's empowerment in the two policy areas.

\section{Accountability}

In both economic governance and trade policy, the EP requested more information from the Commission. This concerned reporting and scrutiny tools as well as enhanced access to documents or data. As we show in this section, the EP was successful in both regards.

When in autumn 2010 the Commission tabled a series of proposals to reform EU economic governance ('Six-Pack'), the EP was co-decider in four of the six legislative acts. The fact that these measures were presented as a 
package allowed the EP to link issues. More precisely, the EP made the adoption of the entire legislative package conditional on concessions regarding further institutional empowerment (Interviews 2, 7). This enabled the EP to introduce the 'Economic Dialogue'. Using this scrutiny tool, the EP can invite the Presidents of the Council, Commission, European Council, and Eurogroup to discuss decisions related to budgetary surveillance in the euro area. Moreover, the EP may also invite member states affected by these decisions to an exchange of views (Regulation 1173/2011, Art. 3). The EP managed to insert the Economic Dialogue even into that regulation of the Six-Pack where it was not a co-decider (Regulation 1177/2011, Art. 2a; O'Keeffe et al. 2016: 226f). Hence, by issuing 'a little friendly blackmail not to adopt the rest of the legislation' (Interview 2), the EP used its veto right in four of the six legislative acts to obtain institutional concessions also in those two where it only had to be consulted. This is a clear instance of arena linking.

Roughly one year after the Six-Pack proposal, the Commission tabled two further legislative acts (the 'Two-Pack'). This initiative offered the EP less opportunity to link issues as it consisted of only two regulations that were hardly related in substance. However, given that the Two-pack was considered highly urgent by the member states (Bressanelli and Chelotti 2016: 520f), while it was publically less salient than the Six-Pack (Laffan and Schlosser 2016: 241), the EP embarked on a different strategy, namely delaying (Interviews 5, 6E, 8). As one EP official explained:

[...] the other part is not giving you anything substantial, and then you say 'ok, there is no deal' and then you wait. [...] it just meant that we sat in a few trialogue negotiations where nothing moved essentially (Interview 5).

Despite considerable pressure from the Commission and the European Council, which repeatedly 'invite(d) the legislators to find an agreement' (European Council 2012a: 9) emphasizing the 'immediate priority' and the need for a 'rapid adoption' (European Council 2012b: 2), the EP stuck to its strategy. As a result, the Economic Dialogue was extended to a much wider range of issues (Regulation 472/2013, Art. 3, 7, 14, 18). For instance, the EP can now also invite representatives of the so-called 'Troika' (International Monetary Fund, European Central Bank, Commission) (Art. 3.9). Moreover, the Commission needs to inform the EP of measures recommended and adopted under enhanced surveillance (Art. 3.1) and it shall communicate its assessment on a quarterly basis (Art. 3.5). In addition, the Commission shall orally inform the Chair and Vice-Chairs of the EP's competent committee of progress made in the preparation of draft macroeconomic adjustment programmes (Art. 7.1).

Next to the Six-Pack and Two-Pack, member states aimed at further enhancing budgetary discipline in the EU by shaping the so-called Fiscal Compact (TSCG). Although the EP had no formal role in the intergovernmental 
negotiations, it fully participated in the working group that negotiated the treaty text. Concerning better reporting and scrutiny tools, the EP managed to oblige the President of the Euro Summit to present a report to the EP after each meeting (Art 12.5 TSCG). This achievement was the result of an 'alliance' with some member states. As opposed to the Six-Pack and Two-Pack negotiations, the Fiscal Compact required de facto unanimity among member states (Tsebelis and Hahm 2014: 1389). This implies that the support of only one Member State may suffice to obtain an institutional empowerment. Indeed, in a resolution on the ongoing negotiations of 18 January 2012, the EP 'notes the support of many Member States for some of its proposals made at the meeting of 12 January 2012' (EP 2012: 1). In the negotiation round following this meeting, the new reporting duties were inserted into the treaty text (European Council 2012d: 9). In the negotiation draft that preceded the meeting, by contrast, the EP was not mentioned at all in connection with Euro Summits (European Council 2012c).

Regarding trade agreements, the EP's demands for more information from the Commission and Council started early on with negotiations of the SWIFT Interim Agreement (2009). The American-European exchange of financial data from SWIFT became salient following a leak into the press (Köppel 2011: 17). Although the Commission and Council were aware of the EP's new rights in the negotiations that came with the Lisbon Treaty (Monar 2010), they disregarded the EP's demands communicated in a resolution on the SWIFT Interim Agreement. In this resolution, the EP set conditions for its consent to the agreement: among other demands, it claimed more information and access to documents (EP 2009). In a debate with the President-in-Office of the Council, MEPs repeated their conditions for consent, especially 'to be kept fully informed' about negotiations (EP 2010a). Ignoring the EP's resolution, in November 2009, one day before the EP would acquire the right to consent to agreements as per Lisbon Treaty, the EU agreed on the SWIFT Interim Agreement with the United States (US).

The EU's decision to sign the SWIFT Interim Agreement without taking into account the EP's request provoked a strong reaction from the EP, which refused to ratify the agreement in February 2010 (Monar 2010). Thereby, the EP sanctioned the Commission and the Council for their refusal to grant it more informal scrutiny rights: When MEPs withheld their consent to the SWIFT Interim Agreement, the EP repeated its demand for more information at all stages of negotiations and complained about the Commission's and the Council's unwillingness to provide full information (EP 2010b).

This required a renegotiation of the agreement, eventually leading to the SWIFT Agreement. After the EP had 'sanctioned' the Commission and the Council, the latter were more willing to provide information to the EP. The negotiation mandate for the new agreement included an explicit commitment by the Commission to take into account the EP's demands as laid out 
in its resolution of May 2010 (Commission 2010; EP 2010e). The Council, too, affirmed that it would provide the EP with all information required (EP 2010a). This was acknowledged by the EP when, in 2010, it released a resolution stating that it '[w]elcome[s] the new spirit of cooperation demonstrated by the Commission and the Council' (EP 2010b). Although the EP asked for even more information and access to documents, it had successfully applied a sanctioning strategy, thereby enhancing the right to scrutinize the negotiation of the SWIFT Agreement. Hence, the EP obtained an institutional empowerment in the form of being immediately and fully informed at all stages of negotiations.

Regarding better access to documents and data in the area of economic governance, the EP's demands coincided with its requests for enhanced reporting duties on the part of the Commission. In connection with the Economic Dialogue, for instance, the Commission needs to inform the EP on a regular basis (Fasone 2014: 176). In connection with the Two-Pack, the Commission must communicate its assessment of countries under post-programme surveillance to the EP every six months (Regulation 472/2013, Art. 14.3). These rights were granted in combination with the enhanced scrutiny tools described above. Thus, the EP used the same strategies to achieve them, namely issue- and arena-linking in the case of the Six-Pack, and delaying in the case of the Two-Pack negotiations (see above).

This was different in trade policy, where documents and data not only concern inter-institutional relations but also classified documents about negotiations with third actors. Over the course of the highly politicized ACTA negotiations (subsequent to SWIFT) (Dür and Mateo 2014), the EP requested that the Commission 'immediately make all documents [...] publicly available' (EP 2010c). The Commission ignored these demands. This only changed partly when, in 2012, citizen groups organized massive public protest against ACTA (Dür and Mateo 2014; Interviews 3, 6T). The Commission's decision to sign the agreement nevertheless provoked the EP to reject ACTA with an overwhelming majority (EP 2010c, 2010d; Interview 6T).

This strategy of sanctioning had far-reaching consequences for the subsequent TTIP negotiations (since 2013) as this time the Commission took the EP much more seriously at all stages of negotiations. In a resolution published even before the Council authorized the Commission's negotiation mandate (Interview 13), the EP set conditions for its approval of TTIP (EP 2013). It also requested the Commission to make the negotiation mandate public - a demand it had made on ACTA, too. This time the EP's request was taken seriously (Interviews 13, 14). Next to the negotiation mandate, the EP got access to all negotiation documents. Furthermore, the new Juncker Commission with trade commissioner Malmström put a great deal of effort into making the TTIP negotiations more transparent than earlier negotiations and conducting TTIP closely together with the EP (Webb 
2015). Among these efforts were: publish negotiation texts which the Commission shared with the EP and the Council; provide access to TTIP texts to all EU member states and MEPs; classify less negotiation documents (Commission 2014).

Despite these efforts, negotiations were still publicly controversial (Akhtar and Jones 2014). One of the most important concerns revolved around transparency. The EP requested that all documents should be made accessible to all MEPs and not just to those in relevant parliamentary committees and in responsible positions (Interviews 11, 13). Moreover, the EP requested the Commission to make documents accessible that were co-authored by the US (Interview 13). In doing so, the EP basically extended the demand for public access to documents of the negotiation partner. In its resolution, the EP communicated that the Commission should translate its 'transparency efforts into meaningful practical results, inter alia by reaching agreements with the US side to improve transparency, including access to all negotiation documents for the Members of the European Parliament, including consolidated texts' (EP 2015a).

In order to realize its demands, the EP mobilized third actors that were in favour of its empowerment: The EP teamed up with civil society organizations and the European Ombudsman to pressure the Commission into making more negotiation documents available to the public (Crisp 2014; EP 2015b). The European Ombudsman, first, launched a public consultation on TTIP's transparency (Ombudsman 2014). Second, she opened an own-initiative inquiry in 2014 regarding transparency of TTIP (Ombudsman 2014). Third, civil society organizations together with MEPs filed a complaint to the European Ombudsman regarding the Commission's secrecy on negotiation documents (Crisp 2014). On top of this, the EP joined in on citizens' demands for more information on TIIP when civil society organizations started an initiative of sending thousands of automated emails to the Commission concerning the lack of transparency (Interview 11).

The mobilization strategy was successful: in 2015, the EP communicated that all MEPs get access to all categories of confidential documents related to TTIP, including consolidated texts that reflect positions by the US (EP 2015b). This was the result of negotiations between the Commission and the EP with the backing of civil society and the European Ombudsman (EP 2015b). 'As a result of pressure from the European Parliament, the European public and the EU Ombudsman, the European Commission [...] made an unprecedented number of documents available' (EP 2015b; italics as in original). These new rules established the infamous 'reading room', in which all MEPs can consult classified documents (Interview 11). Apart from the classified documents, all MEPs got access to limited documents through a newly established database (Interview 13). 


\section{Decision-making}

In the course of eurozone crisis management, the EP obtained the right to participate as a full negotiation partner in decision-making fora where the Lisbon Treaty had not granted it any powers going beyond the right to be consulted. Moreover, the EP attempted to influence decision-making through an empowerment outside the official fora. This included informal involvement in appointment procedures of executive staff and the right to establish a conference with national parliaments. As regards trade policy, the EP sought to go beyond its veto right on trade agreements by requesting to authorize the Commission's negotiation mandate and to sit at the negotiation table. While especially the latter demand proved unsuccessful, the EP managed to influence decisions on TTIP by expanding its powers outside the usual decision-making fora.

In the Six-Pack negotiations, the EP was a formal co-decider in only four of the six legislative acts. Still, it managed to obtain the informal right to participate as a de facto co-decider on all six files. This is a prime example of arenalinking: By credibly threatening to block the four regulations under codecision, the EP obtained informal co-decision rights in an arena where it formally only had to be consulted (Interviews 2, 6E, 7). One EU official described this strategy very explicitly from the Council's point of view:

you come to the point where you say: 'Look, Parliament, on those two we are happy to have your opinion, but in principle we don't have to care'. Now, if you say that, you are in big trouble because then you won't get your compromise on the other four. [...] that basically means that the Parliament was negotiating on those two where it was not co-decision-maker [...] The Parliament has basically gained a full role of co-legislator de facto (Interview 7, italics added).

A similar pattern can be seen in the Fiscal Compact negotiations. Although the EP does not enjoy any formal rights of decision-making when it comes to international treaties outside EU law, it obtained the informal right of fully participating in the working group that negotiated the treaty text (Interviews $1 \mathrm{E}$, $6 \mathrm{E}, 7)$. One reason for this is the fact that at the time the treaty negotiations took place, the Two-pack legislation, in which the EP was involved as co-legislator, had already been launched. This allowed the EP to link the two arenas. As one participant in the negotiations explained, the issues agreed on in the Fiscal Compact negotiations were directly introduced to the Two-pack negotiations, in order to keep the treaty as compatible with EU law as possible (Interview 6E). Thus, the EP could threaten to block the Two-Pack if its preferences were not considered in the Fiscal Compact negotiations.

Moreover, the EP tried to mobilize public opinion. More precisely, influential MEPs publicly demanded the participation of the EP in the treaty negotiations. ALDE leader Guy Verhofstadt insisted on fully involving the EP in the drafting process as any new treaty would only be acceptable 'if the 
community method and democratic control are fully respected' (Euractiv 2011a). PES leader Sergei Stanishev established a direct link between the alleged public endorsement of the EP's empowerment and its participation in the treaty negotiations:

in Europe people demand more democracy at the European level. The European Parliament is the only European institution which is elected directly by the citizens and [...] the role of this institution should be respected by everyone, every country and every other institution in the European Union (Euractiv 2011b).

Also EP President Martin Schulz demanded that the EP 'has to be included' (Darnstädt 2011) in the treaty negotiations. As described above, the EP also managed to win support of single member states, which led to the provision that the EP President may be invited to be heard at Euro summits (Art 12.5 TSCG).

Apart from directly participating in decision-making fora, the EP has attempted to influence decision-making through venues outside the official arenas. One strategy has been to 'move first' and to establish a practice that is difficult to undo by member states. The EP's decision to organize hearings in appointment procedures where it formally does not have an institutional role is a case in point. In the context of the Six-Pack legislation, the EP sought to take influence on the monitoring of programme countries by becoming part of the appointment processes of 'Troika' and European Stability Mechanism. It organized hearings for the candidates in question and then made recommendations. Although these recommendations are not binding, the fact that the EP can organize these hearings is an informal institutional empowerment (Interview 6E).

Another venue outside the usual decision-making fora is the so-called inter-parliamentary conference. By allying with some member states in the Fiscal Compact negotiations, the EP obtained the right to organize a conference with national parliaments to discuss budgetary policies and other issues covered by the Fiscal Compact (Art. 13 TSCG; Interviews 1E, 6E, 7). ${ }^{1}$ Although its actual effect is debatable, this conference is regarded with distrust by some governments, as it could become an occasion for the EP to influence national budgetary policies (Interview 7).

Regarding trade agreements, the EP asked on several occasions, such as ACTA, to sit at the negotiation table with the Commission (Interview 3). As this direct access to the negotiations has not been conceded to the EP, it 'moved first' in the case of TTIP by setting up parliamentary sessions and hearings with representatives from the US delegation (Interview 12). Some MEPs also had direct meetings with American officials in Washington to discuss the negotiations (Interview 12). These meetings mainly revolved around gathering more information (Interview 13). Retrieving more information from sources other than the Commission was crucial for the EP as one of its main 
concerns was the negotiations' lack of transparency (Jančić 2016: 900). The EP unilaterally introduced the informal rule of talking directly to the negotiation partner. This is a big step towards empowering the EP (Interview 1T). In fact, in the current Brexit negotiations, the EP appointed Guy Verhofstadt as its 'coordinator' whereby he developed into an important interlocutor who co-shapes negotiations (Interview 16). Given that the Commission can hardly prevent the EP from setting up meetings with the negotiation partner unilaterally, the EP's initiative to invite representatives from the US delegation qualifies as a strategy of moving first.

\section{Comparison and negative cases}

In the previous section we find that the EP had particular success in empowering itself by using bargaining strategies based on a veto right: obstructing decision-making through delaying (economic governance), sanctioning (trade agreements), and linking arenas (economic governance). What are their conditions for success or failure? In order to answer this question, we need to look at negative cases where the EP failed with its institutional demands.

In the area of eurozone reform, we find many instances where the EP was not able to realize its initial requests. Not each of these instances is automatically a case of failure, as the EP often starts negotiations on extreme demands to have more leeway in bargaining and ultimately achieve a more moderate compromise. The request for Eurobonds in the Six-Pack negotiations is a case in point where the EP already considered it a success to commit the Commission to draft a Green Paper despite many member states' outright rejection of the proposal (Interview 2).

A clearly negative case where the EP failed with its demands was the establishment of the ESM. Here, the EP was excluded from treaty negotiations, and it did not obtain any role in the rescue mechanism's institutional design. Comparing the ESM to the Fiscal Compact may help understand this failure as both cases are intergovernmental treaty negotiations where the EP had opportunities to link arenas. In order to establish the ESM, it was deemed necessary to change Article 136 TFEU (De Witte 2011: 5f). The simplified treaty revision procedure used for that purpose required the EP's initial consent, and thus provided an opportunity for the EP to link its approval to its demands for being included in the ESM negotiations (EP 2012). Yet, while arena-linking succeeded in the case of the Fiscal Compact (see above), it failed in the case of the ESM and the EP's demands were entirely ignored.

We argue that the reason for these varying outcomes lies in the negotiators' preferences and their cost-benefit calculations. More specifically, arena-linking is successful only if the costs of accommodating the EP are smaller for the Commission or member states than the benefits of the 
agreement blocked by the EP. This was the case in the Fiscal Compact: as it aims at enforcing budgetary discipline, member states did not have to fear major distributional consequences by including the EP in the negotiations. Thus, the costs of accommodating the EP were smaller than the benefits of an agreement on the Two-Pack linked by the EP (see above). Regarding the ESM, by contrast, the actual commitment of budgetary means was at stake. Hence, the costs of accommodating the EP concerned the potential loss of control over considerable amounts of tax payers' money. This exceeded the benefits of amending article 136 with the simplified revision procedure. In short, the success of veto-based strategies depends on the distributional consequences for the other negotiators.

In shaping international agreements, the degree to which the EP can rely on veto-based strategies is limited. This is because the EP's formal right is restricted to the ratification of an agreement at the very end of negotiations and cannot be used to great effect for delaying or arena-linking. Therefore, compared to economic governance, the EP relies more extensively on indirect bargaining strategies such as mobilizing public opinion. This was true in the ACTA negotiations where the EP used this strategy to demand more accountability rights in the form of information and access to negotiation documents (EP 2010c). It tried to create a coalition of experts and like-minded NGOs against the Commission (Interview 6T), but ultimately failed with its requests. Although the EP mobilized many NGOs, these were mainly resource-poor citizen groups. In addition, the EP and like-minded NGOs faced a large coalition of resource-intense business and industry groups mobilizing in favour of ACTA (Dür and Mateo 2014). The asymmetry of resources and the simultaneous mobilization in favour of ACTA explain why the EP failed with its bargaining strategy. Hence, a condition for success of mobilizing public opinion is to turn to powerful actors who share the EP's preferences.

\section{Conclusion}

Comparing economic governance and trade policy, this article analyzes how the EP pushed its formal and informal rights beyond the provisions of the Lisbon Treaty. Through usage of multiple strategies, the EP increased its powers as regards both accountability and decision-making. In particular when it comes to venues outside the official fora of decision-making, the EP 'forced' the other actors to grant it more powers by unilaterally introducing new rules to its benefit (moving first). Other strategies successfully employed in both policies were obstructing the decision-making process through delaying (in economic governance) and sanctioning (in trade policy) as well as mobilizing public opinion. By contrast, we found strategies of arena linking as well as alliance building with single member states only in the area of economic governance. 
Using these strategies, the EP improved its reporting and scrutiny tools and was granted access to relevant documents and data (accountability rights). Moreover, the EP increased its formal and informal rights regarding the participation in official decision-making fora as well as relevant outside venues, such as appointment procedures or, in the case of trade agreements, direct meetings with the EU's negotiation partner (decision-making rights). These results demonstrate the EP's efforts and its success in empowering itself through multiple bargaining strategies between treaty changes and over the course of day-to-day decision-making.

To be sure, an increase in institutional rights does not automatically lead to more influence over policy outcomes. This argument has been made in particular with regard to the EP's role in eurozone crisis management (e.g. Koop and Dionigi 2017). First, it has been argued that the EP was not able to translate its newly gained powers into real authority on policy outcomes (Bressanelli and Chelotti 2016, 2018; Warren 2018). Second, there are 'negative' cases in which the EP failed to acquire new rights. In economic governance, the establishment of the ESM is a case in point. In trade, ACTA is an example where the EP failed with its strategy of mobilizing public opinion due to a resource-intense counter-coalition of business groups. While we explore some conditions that prevented the EP from acquiring further rights, the primary aim of this article is to show how the EP succeeded in increasing its powers as a pre-condition for any (future) influence over policy outcomes.

Finally, more participation rights for the EP and more control over executive actors provide opportunities for increased politicization at the EU level, doing justice to public contention of EU issues and representing citizens' concerns in the decision-making process. Yet, by bargaining for institutional rights behind closed doors, the EP may be perceived as being more interested in empowering itself than in representing EU citizens. Moreover, dynamics of self-empowerment can face limits especially when the EP pursues conflicting goals: reaching particular policy outcomes, empowering itself, or shaping the institutional setting of a policy. ${ }^{2}$ How the EP reacts in such situations remains an important area of future research.

\section{Notes}

1. According to the negotiation draft preceding the meeting of 18 January 2012, in which the EP secured the support of some member states, the EP should only be invited to meet with representatives of national parliaments.

2. We wish to thank Jonathan Zeitlin for pointing this out.

\section{Acknowledgments}

An earlier version of this article was presented at the workshop on 'Transformation or collapse? Politicization or integration in postfunctionalist times' at ACCESS Europe, 13- 
14 October, 2017. We thank the workshop organizers Jonathan Zeitlin and Francesco Nicoli and workshop participants for helpful feedback. We gratefully acknowledge discussions with Adrienne Héritier and Catherine Moury as well as valuable comments by three anonymous reviewers.

\section{Disclosure statement}

No potential conflict of interest was reported by the authors.

\section{Notes on contributors}

Katharina L. Meissner is assistant professor at the Centre for European Integration Research (EIF), Department for Political Science, University of Vienna.

Magnus G. Schoeller is postdoctoral researcher at the Centre for European Integration Research (EIF), Department for Political Science, University of Vienna.

\section{References}

Akhtar, S.I. and Jones, V.C. (2014) Transatlantic trade and investment partnership (TTIP) negotiations, congressional research service CRS report 7-5700.

Beach, D. and Pedersen, R.B. (2013) Process-Tracing Methods: Foundations and Guidelines, Ann Arbor: University of Michigan Press.

Bressanelli, E. and Chelotti, N. (2016) 'The shadow of the European Council. Understanding legislation on economic governance', Journal of European Integration 38(5): 511-25.

Bressanelli, E. and Chelotti, N. (2018) 'The European Parliament and economic governance: explaining a case of limited influence', The Journal of Legislative Studies 24(1): 72-89.

Commission (2010). Negotiation directives, available at http://www.statewatch.org/ news/2010/aug/eu-us-general-dp-agreement-mandate-2.pdf (accessed 30 June 2017).

Commission (2014) Communication to the Commission Concerning Transparency in TTIP Negotiations (C(2014) 9052 final), available at http://ec.europa.eu/transparency/ regdoc/rep/3/2014/EN/3-2014-9052-EN-1-1.PDF (accessed 13 November 2017).

Crisp, J. (2014) 'EU ombudsman demands more TTIP transparency', Euractiv, available at http://www.euractiv.com/sections/trade-industry/eu-ombudsman-demands-morettip-transparency-303831 (accessed 9 March 2015).

Darnstädt, T. (2011, December 16) 'The pitfalls of the merkozy fiscal pact', Spiegel, available at http://www.spiegel.de/international/europe/more-problems-than-answersthe-pitfalls-of-the-merkozy-fiscal-pact-a-803923.html (accessed 24 April 2017).

De Witte, B. (2011) The European Treaty Amendment for the Creation of a Financial Stability Mechanism, European Policy Analysis 6epa, Stockholm: Swedish Institute for European Policy Studies.

Dür, A. and Mateo, G. (2014) 'Public opinion and interest group influence: how citizen groups derailed the anti-counterfeiting trade agreement', Journal of European Public Policy 21(8): 1199-217.

EP (2009) European Parliament Resolution of 17 September 2009 on the Envisaged International Agreement to Make Available to the United States Treasury 
Department Financial Payment Messaging Data to Prevent and Combat Terrorism and Terrorist Financing (P7_TA(2009)0016), available at http://www.europarl.europa.eu/ sides/getDoc.do?type=TA\&reference=P7-TA-2009-0016\&language=EN (accessed 22 August 2017).

EP (2010a) Debates, available at http://www.europarl.europa.eu/sides/getDoc.do? pubRef=-\%2f\%2fEP\%2f\%2fTEXT\%2bCRE\%2b20100120\%2bITEM-010\%2bDOC\% 2bXML\%2bV0\%2f\%2fEN\&language=EN (accessed 30 June 2017).

EP (2010b) Motion for a Resolution, available at http://www.europarl.europa.eu/sides/ getDoc.do?type $=$ MOTION\&reference $=$ B7-2010-0243\&language $=E N$ (accessed 30 June 2017).

EP (2010c) European Parliament Resolution of 10 March 2010 on the Transparency and State of Play of the ACTA Negotiations, available at http://www.europarl.europa.eu/ sides/getDoc.do?pubRef=-//EP//TEXT+TA+P7-TA-2010-0058+0+DOC+XML+V0//EN (accessed 30 June 2017).

EP (2010d) European Parliament Resolution of 24 November 2010 on the AntiCounterfeiting Trade Agreement (ACTA), available at http://www.europarl.europa. eu/sides/getDoc.do?pubRef=-//EP//TEXT+TA+P7-TA-2010-0432+0+DOC+XML+V0// EN (accessed 30 June 2017).

EP (2010e) European Parliament Resolution of 5 May 2010 on the Recommendation from the Commission to the Council to Authorise the Opening of Negotiations for an Agreement between the European Union and the United States of America to Make Available to the United States Treasury Department Financial Messaging Data to Prevent and Combat Terrorism and Terrorist Financing, available at http://www. europarl.europa.eu/sides/getDoc.do?pubRef=-//EP//TEXT+TA+P7-TA-2010-0143+0 $+\mathrm{DOC}+\mathrm{XML}+\mathrm{V0} / / \mathrm{EN}$ (accessed 28 August 2017).

EP (2012) Conclusions of the European Council Meeting (8-9 December) on a Draft International Agreement on a Fiscal Stability Union, European Parliament Resolution of 18 January 2012, available at http://www.europarl.europa.eu/sides/getDoc.do? pubRef=-//EP//TEXT+TA+P7-TA-2012-0002+0+DOC+XML+V0//EN (accessed 22 August 2017).

EP (2013) European Parliament Resolution of 23 May 2013 on EU Trade and Investment Negotiations with the United States of America, available at http://www.europarl. europa.eu/sides/getDoc.do?pubRef=-//EP//TEXT+TA+P7-TA-2013-0227+0+DOC $+\mathrm{XML}+\mathrm{V} 0 / / \mathrm{EN}$ (accessed 30 June 2017).

EP (2015a) European Parliament Resolution of 8 July 2015 Containing the European Parliament's Recommendations to the European Commission on the Negotiations for the Transatlantic Trade and Investment Partnership (TTIP), available at http://www. europarl.europa.eu/sides/getDoc.do?pubRef=-//EP//TEXT+TA+P8-TA-2015-0252+0 +DOC+XML+V0//EN (accessed 4 October 2016).

EP (2015b) All MEPs to have access to all confidential TTIP documents, available at http://www.europarl.europa.eu/sides/getDoc.do?type=IM-PRESS\&reference= 20151202IPR05759\&language=EN\&format=XML (accessed 4 October 2016).

Euractiv (2011a, December 15) 'Europe's new treaty: towards a multi-speed union', Euractiv, available at http://www.euractiv.com/section/future-eu/linksdossier/europe-s-newtreaty-towards-a-multi-speed-union/\#ea-accordion-positions (accessed 24 April 2017).

Euractiv (2011b, December 13) 'PES leader: "golden rule' should not be imposed"', Euractiv, available at http://www.euractiv.com/section/euro-finance/interview/pesleader-golden-rule-should-not-be-imposed/ (accessed 24 April 2017).

European Council (2012a, October 19) Conclusions, available at http://data.consilium. europa.eu/doc/document/ST-156-2012-INIT/en/pdf (accessed 29 August 2017). 
European Council (2012b, December 14) Conclusions, available at https://www. consilium.europa.eu/uedocs/cms_data/docs/pressdata/en/ec/134353.pdf (accessed 29 August 2017).

European Council (2012c) Draft: treaty on stability, coordination and governance in the economic and monetary union, 10 January.

European Council (2012d) Draft: treaty on stability, coordination and governance in the economic and monetary union, 19 January.

Farrell, H. and Héritier, A. (2003) 'Formal and informal institutions under codecision: continuous constitution-building in Europe', Governance 16(4): 577-600.

Farrell, H. and Héritier, A. (2007) 'Codecision and institutional change', West European Politics 30(2): 285-300.

Fasone, C. (2014) 'European economic governance and parliamentary representation. What place for the European Parliament?', European Law Journal 20(2): 164-85.

Fromage, D. (2018) 'The European Parliament in the post-crisis era: an institution empowered on paper only?', Journal of European Integration 40(3): 281-94.

Gino, F. and Moore, D. (2008) 'Using final deadlines strategically in negotiation', Negotiation and Conflict Management Research 1(4): 371-88.

Héritier, A. (1996) 'The accommodation of diversity in European policy-making and its outcomes: regulatory policy as a patchwork', Journal of European Public Policy 3(2): 149-67.

Héritier, A. (2007) Explaining Institutional Change in Europe, Oxford: Oxford University Press

Héritier, A., Moury, C., Schoeller, M.G., Meissner, K.L. and Mota, I. (2015) The European Parliament as a Driving Force of Constitutionalisation, available at http://www. europarl.europa.eu/RegData/etudes/STUD/2015/536467/IPOL_STU

(2015)536467_EN.pdf (accessed 29 January 2019).

Hix, S. and Høyland, B. (2013) 'Empowerment of the European Parliament', Annual Review of Political Science 16(1): 171-89.

Jančić, D. (2016) 'The role of the European Parliament and the US congress in shaping transatlantic relations: TTIP, NSA surveillance, and CIA renditions', JCMS: Journal of Common Market Studies 54(4): 896-912.

Koop, C. and Dionigi, M.K. (2017) Losing Out on Substance but Winning Procedurally? The European Parliament and Accountability in Crisis Legislation, unpublished article manuscript.

Köppel, Johannes (2011) The SWIFT affair: swiss banking secrecy and the fight against terrorist financing, The Graduate Institute 2011-9.

Laffan, B. and Schlosser, P. (2016) 'Public finances in Europe: fortifying EU economic governance in the shadow of the crisis', Journal of European Integration 38(3): 237-49.

Liefferink, D. and Andersen, M.S. (1998) 'Strategies of the 'green' member states in EU environmental policy-making', Journal of European Public Policy 5(2): 254-70.

Mahoney, J. and Goertz, G. (2004) 'The possibility principle: choosing negative cases in comparative research', American Political Science Review 98(4): 653-69.

Majone, G. (2010) 'Transaction-cost efficiency and the democratic deficit', Journal of European Public Policy 17(2): 150-75.

Mikkelsen, K.S. (2017) 'Negative case selection: justifications and consequences for settheoretic MMR', Sociological Methods \& Research 46(4): 739-71.

Monar, J. (2010) 'The rejection of the EU-US SWIFT interim agreement by the European parliament: a historic vote and its implications', European Foreign Affairs Review 15 (2): $143-51$. 
Müller, W.C., Strøm, K. and Bergman, T. (2003) 'Parliamentary democracy: promise and problems', in K. Strøm, W.C. Müller \& T. Bergman (eds.), Delegation and Accountability in Parliamentary Democracies, New York: Oxford University Press, pp. 3-33.

O'Keeffe, M., Salines, M. and Wieczorek, M. (2016) 'The European Parliament's strategy in EU economic and financial reform' Journal of European Public Policy 23(2): 217-35.

Ombudsman (2014) Decision of the European Ombudsman Closing her Own-Initiative Inquiry OI/10/2014/RA Concerning the European Commission, available at http:// www.ombudsman.europa.eu/en/cases/decision.faces/en/58668/html.bookmark (accessed 4 October 2016).

Reh, C., Héritier, A., Bressanelli, E. and Koop, C. (2013) 'The informal politics of legislation: explaining secluded decision making in the European Union', Comparative Political Studies 46(9): 1112-42.

Rittberger, B. (2014) 'Integration without representation? The European Parliament and the reform of economic governance in the EU', JCMS: Journal of Common Market Studies 52(6): 1174-83.

Rittberger, B. and Schimmelfennig, F. (2006) 'Explaining the constitutionalization of the European Union', Journal of European Public Policy 13(8): 1148-67.

Schimmelfennig, F. (2001) 'The community trap: liberal norms, rhetorical action, and the eastern enlargement of the European Union', International Organization 55(1): 47-80.

Tsebelis, G. and Hahm, H. (2014) 'Suspending vetoes: how the euro countries achieved unanimity in the fiscal compact', Journal of European Public Policy 21(10): 1388-411.

Warren, T. (2018) 'The European Parliament and the eurozone crisis: an exceptional actor?', British Journal of Politics and International Relations 20: 632-51. doi:10. $1177 / 1369148118768141$.

Webb, D. (2015) 'The transatlantic trade and investment partnership (TTIP)', House of Commons Library Standard Note. UK Parliament Report, United Kingdom, available at http://www.parliament.uk/business/publications/research/briefing-papers/SN06688/ the-transatlantic-trade-and-investment-partnership-ttip (accessed 10 March 2015).

Zeitlin, J., Nicoli, F. and Laffan, B. (2019) 'Introduction: the European Union beyond the polycrisis: integration and politicization in an age of shifting cleavages', this collection.

Interviews

Economic Governance

Interview 1E (2015): European Parliament, senior official. Brussels, Belgium, 2 February. Interview 2 (2015): European Parliament, MEP, Brussels, Belgium, 4 February.

Interview 5 (2015): European Parliament, senior official. Brussels, Belgium, 10 February. Interview 6E (2015): EU officials. Brussels, Belgium, 11 February.

Interview 7 (2015): General Secretariat of the Council, senior official. Brussels, Belgium, 11 February.

Interview 8 (2015): European Parliament, senior official. Brussels, Belgium, 12 February. Trade Policy

Interview 1T (2015): European Commission. Brussels, Belgium. February 02, 2015. Interview 3 (2015): European Commission. Brussels, Belgium. February 09, 2015. Interview 6T (2015): European Parliament. Brussels, Belgium. February 11, 2015. Interview 11 (2015): European Parliament. Brussels, Belgium. February 26, 2015. Interview 12 (2015): European Parliament. Brussels, Belgium. February 27, 2015. Interview 13 (2015): European Commission. Brussels, Belgium. February 27, 2015. Interview 14 (2015): European Commission. Brussels, Belgium. February 27, 2015. Interview 16 (2018): European Parliament. Brussels, Belgium. October 9, 2018. 